\title{
ПРО ПЕРСПЕКТИВИ ШИРШОГО ВИКОРИСТАННЯ ПОНЯТЬ КОМПЛЕМЕНТАРНОСТІ ТА КОНГРУЕНТНОСТІ В ПРАКТИЧНІЙ МЕДИЦИНІ
}

О. П. Мінцер, Л. Ю. Бабінцева

Національна медична академія післядипломної освіти імені П. Л. Шупика

\begin{abstract}
Розглянуто можливості ширшого застосування понять комплементарності та конгруентності в медицині. Пропонується використовувати прості функціонали для формалізації лікувальної стратегії, що є відображенням діагностичного висновку та подальшого конформного відображення страхових дій.
\end{abstract}

Ключові слова: комплементарність і конгруентність медичної допомоги, кількісні характеристики комплементарності та конгруентності, комплексне оцінювання медичної допомоги, формалізація лікувальної тактики.

\section{О ПЕРСПЕКТИВАХ БОЛЕЕ ШИРОКОГО ИСПОЛЬЗОВАНИЯ ПОНЯТИЙ КОМПЛЕМЕНТАРНОСТИ И КОНГРУЭНТНОСТИ В ПРАКТИЧЕСКОЙ МЕДИЦИНЕ}

\author{
О. П. Минцер, Л. Ю. Бабинцева
}

Национальная медицинская академия последипломного обучения имени П. Л. Шупика

\begin{abstract}
Рассмотрены возможности широкого применения понятий комплементарности и конгруэнтности в медицине. Предлагается использовать простые функционалы для формализации лечебной стратегии, являющиеся отображением диагностического заключения и последующего конформного отображения страховых действий.
\end{abstract}

Ключевые слова: комплементарность и конгруэнтность медицинской помощи, количественные характеристики комплементарности и конгруэнтности, комплексная оценка медицинской помощи, формализация лечебной тактики.

\section{PROSPECTS OF WIDER USE OF THE OF COMPLEMENTARITY AND CONGRUENCE CONCEPT IN PRACTICAL MEDICINE}

\section{O. P. Mintser, L. Yu. Babintseva \\ P. L. Shupyk National Medical Academy of Postgraduate Education}

\begin{abstract}
It was discussed the possibility of widespread use of the complementarity and congruence concepts in medicine. It is proposed to use a simple functional to formalize therapeutic strategy is a reflection of the diagnostic and follow-conformal mapping conclusion of the insurance operations.
\end{abstract}

\footnotetext{
Key words: complementarity and congruence of medical care, quantitative characteristics of complementarity and congruence, a comprehensive assessment of medical care, the formalization of medical tactics.
}

Вступ. Понад очікування поняття комплементарності досить широко застосовується в клінічній практиці. Опубліковано сотні тисяч робіт, $86 \%$ 3 яких - впродовж останніх 30 років [1]. Очевидно, що комплементарна медицина є відносно новим напрямом світової охорони здоров'я, що швидко розвивається. Більше того, існують й офіційні визначення. Так, відповідно до визначень Інституту комплементарної медицини (Велика Британія) та Національного центру комплементарної й альтернативної медицини (США) під поняттям комплементарної (C) О. П. Мінцер, Л. Ю. Бабінцева медицини / терапії / допомоги слід розуміти різні види додаткової терапії, не пов'язаної з лікувальним впливом або хірургічним втручанням $[1,2,14]$. У ряді досліджень під комплементарним ефектом у медицині розуміють концентрацію, мобілізацію та перерозподіл внутрішніх резервів і можливостей організму пацієнта, що не можуть бути задіяні та використані традиційними лікувальними засобами [2]. У такому випадку доповнюючий ефект до сягається, як правило, за допомогою застосування спеціальних технологій, технік, практик [8]. 
Іншими словами, термін комплементарна або доповнююча медицина / терапія об'єднує всі напрями допоміжної лікувальної практики, що виходять за рамки класичних уявлень офіційної медицини та відповідних протоколів лікування. При цьому вважають, що поняття комплементарної медицини вужче, проте є більш доведеним, ніж поняття альтернативної медицини. Підкреслимо, що визначення та поняття комплементарної медицини впроваджено й в освітній процес [6, 7].

На тепер напрям комплементарної медицини найбільший розвиток отримав у США та Великій Британії.

Саме у Великій Британії найбільше розроблена й законодавча база, що регламентує використання як комплементарної медицини, так й інтегративних підходів до лікування. Там же офіційно затверджено протокол про основні положення, що стосуються альтернативної та комплементарної медицини.

Прийнято вважати [1], що головними відмінними особливостями комплементарної терапії є:

1. Повніший облік індивідуальних особливостей організму пацієнта в загальній (поєднаній) програмі спеціального лікування.

2. Використання в лікувальному процесі внутрішніх резервів і можливостей організму пацієнта.

3. Багатоаспектність і комплексність впливу на організм пацієнта.

4. Можливість оптимізації широкого арсеналу лікувальних і доповнюючих засобів.

5. Гармонійне та взаємодоповнююче поєднання в лікувальному процесі конвенціальних методів лікування $з$ доповнюючою терапією.

Відмінність комплементарної допомоги від паліативної полягає в тому, що паліативна допомога спрямовано застосовується до пацієнтів, які мають, як правило, несприятливий прогноз або яким не призначено радикальний метод лікування. Головний же вектор спрямованості комплементарної медицини пов'язаний із посиленням і розвитком позитивних тенденцій лікувального процесу в пацієнтів, які мають у своїй більшості сприятливий прогноз. По суті, комплементарна медицина, хоча й виступає як самостійна категорія, разом із тим $є$ проміжною ланкою, що поєднує аспекти спрямованої лікувальної та паліативної допомоги.

Значно менш поширеним є поняття «конгруентність». Конгруентність може бути введена для визначення математичної відповідності лікувального чинника причині хвороби. Отже, лікувальний чинник, що максимально повно усуває причину хвороби, можна вважати конгруентним, а той, що не усуває, або усуває причину тільки частково, не конгруентним [12].

Конгруентність вводиться й у визначення причини захворювання. Так, наприклад, це поняття використовують при обгрунтуванні діагностичної стратегії в клініці псоріазу як міру невизначеності, бо описано настільки велику кількість умов, при наявності яких «виникає» дане захворювання, що класична математична категорія конгруентності не може бути використана при їх комплексному описі.

В останні роки знайшло широке застосування поняття конгруентності при описі діагностики стану суглобових поверхонь, наприклад, колінного суглоба [11].

Отже, якщо поняття комплементарності давно використовується в практичній медицині, переважно для позначення напряму лікувальних дій (але не тактичних заходів), то конгруентність застосовується для конкретно позначених технологій або визначень. І для конгруентності, й для комплементарності практично повністю відсутня метрика.

Мета роботи: запропонувати концепцію використання термінів конгруентності та комплементарності як системоутворюючих у практичній медицині для підвищення якості надання медичної допомоги населенню. Обгрунтувати їх застосування при формалізації стратегії оцінювання якості надання медичної допомоги.

Матеріал і методи дослідження. Проведено ретроспективне дослідження даних літератури, матеріалів систематичних оглядів. Застосовано методи експертних оцінок, ретроспективного аналізу та метааналізу.

Результати та їх обговорення. Розглядаючи комплементарність методів надання медичної допомоги легко можна виділити чотири головні напрями «додатковості». Це, насамперед, прискорення одужання (досягнення ремісії), зниження частоти ускладнень, прискорення процесів досягнення ремісії (одужання) при лікуванні супутніх патологічних процесів, поліпшення самопочуття пацієнтів. Зрозуміло, що можна виділити й інші напрями. Конкретні узагальнення напрямів повинні бути виділені шляхом досягнення консенсусу в медичних спільнотах, хоча можливі й доцільні локальні (регіональні) та професійні рішення. Завданням же цієї роботи є відпрацювання шляхів комплексного оцінювання обраної стратегії рішення. 
В рамках чотирьох напрямів комплементарно сті сумарна функція обраного лікування описується простим функціоналом:

$$
E=K_{1} C_{1}+K_{2} C_{2}+K_{3} C_{3}+K_{4} C_{4}
$$

де $E$ - ефективність лікування, що виражена в умовних одиницях; $C_{1} ; C_{2} ; C_{3} ; C_{4}$ - комплементарні лікувальні дії; $K_{1} ; K_{2} ; K_{3} ; K_{4}-$ стандартизовані коефіцієнти, що дозволяють забезпечити єдину масштабованість при зіставленні ефективності дії додаткового лікування.

Коефіцієнти при $C$ розраховуються досить просто та зрозумілі пересічним лікарям, а саме, представляють відносини термінів лікування (частоти ускладнень, бальних характеристик самопочуття пацієнтів тощо) без прийнятого комплементарного лікування та після нього. Очевидно, що про ефективність лікувальних дій можна говорити лише при $E$ більшому за 1.

Настільки ж безперечно, що комплексна (сумарна) оцінка $C$ комплементарного лікування не $\epsilon$ адитивною функцією коефіцієнтів при К. На першому етапі вона може бути виражена експертною оцінкою, але в рамках пропонованої методики на підставі відносно невеликої кількості коефіцієнтів.

Істотно складніше оцінити конгруентність лікувальних дій, що позначимо як $R$.

Пропонується виділити два види конгруентності: стратегічну $-R_{g}$ і тактичну $-R_{t}$.

Під стратегічною конгруентністю розуміємо таку узгодженість зміни лікувальної стратегії, щоб забезпечити мінімізацію ймовірності нанесення шкоди здоров'ю пацієнта (наприклад, поява звикання до антибіотиків, збільшення ризику появи суттєвих ускладнень тощо). Мабуть, до стратегічної неузгодженості слід віднести й таку зміну стратегії (плану) лікування, що викликає необумовлене та різке збільшення витрат при лікуванні пацієнта.

Тактична неконгруентність лікувальних дій пов'язана $з$ необумовленою зміною лікарських засобів, необгрунтованим їх дозуванням, неповним вибором додаткових засобів тощо.

Виходячи зі смислового навантаження поняття конгруентності, найпростішим методом їі оцінки $\epsilon$ нормована експертна величина. Очевидно також, що до прийняття єдиної системи стандартів лікувальних дій і системи комплементарності в медицині говорити про кількісну та масштабовану систему обліку конгруентності не доводиться.

В якості швидкого експрес-оцінювання комплементарності та конгруентності терапії цілком може бути використано добуток їх нормованих оцінок.
Отже, математична формалізація проблеми полягає в побудові концептуальної піраміди, в основі якої лежить чотири процеси - Р: конгруентність медичних дій - $R$, їх взаємна комплементарність - Е, облік колокації (пов'язаних патологічних процесів) - V та комплексність - Z - інтегральний облік виявленої в процесі діагностики та лікування пацієнта інформації. Вершиною піраміди $є$ процедура системного оброблення наявної інформації. Загальна концепція може бути представлена логічною формулою $S=F$ (4P) (рис. 1). Підкреслимо, що подібна формалізація стратегічно може конформно відображати діагностичний висновок і стати підставою для об'єктивного та кількісного обгрунтування висновків у страховій медицині.

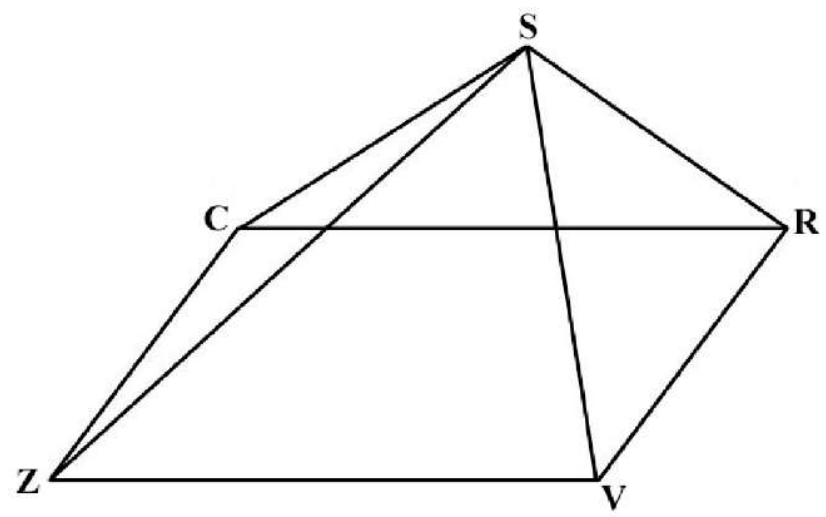

Puc. 1. Концептуальна піраміда оцінювання ефективності медичної стратегії лікування хворого.

Зауважимо, що результатом системного оброблення можуть бути й проекції інтегральної величини $S$ на окремі складові якості надання медичної допомоги. Саме цей аспект проілюструємо на прикладі.

Найширше комплементарність (як прийнята філософія) використовується в онкології, де під нею розуміється сукупність різних прийомів і методів, що можуть застосовуватися на додаток до основного курсу (протоколу) спеціального протипухлинного лікування [13]. Комплементарна терапія в онкології має відношення, насамперед, до інтегративного (комплексного) підходу до лікування, що передбачає, крім самого курсу спеціального протипухлинного лікування, використання широкого арсеналу доповнюючих лікувальних засобів і терапій, а також засобів супроводу, реабілітації, адаптації та профілактики. Зрозуміло, нами використано поняття комплементарної терапії (а не допомоги!), що включає в себе тільки ті доповнюючі засоби та методи, ефективність яких підтверджена, 
описана та доведена відповідною клінічною практикою. Стратегічна конгруентність використаних комплементарних методів терапії при експертній оцінці виявилася рівною 0,7 .

Особливу увагу вважали за необхідне звернути на такі нормовані показники: збільшення прогнозних термінів виживаності $\left(A_{1}\right)$, скорочення часу перебування пацієнта в стаціонарі $\left(\mathrm{A}_{2}\right)$, поліпшення самопочуття пацієнтів - $\mathrm{A}_{3}$. Запропоновано також експертну величину $\mathrm{A}_{4}$, що інтегрально відображає посилення позитивних тенденцій і загальної позитивної динаміки змінення стану пацієнта під час ремісії, а також на етапах реабілітації та адаптації. Тобто, успіх (ефективність) лікування $S$ в розглянутому окремому випадку можна виразити формулою:

$$
S=k A_{1}+\kappa A_{2}+k A_{3}+k A_{4} .
$$

Коефіцієнти перед А, як і при загальній стратегії оцінювання якості медичної допомоги, обиралися

\section{Література}

1. Василенко А. М. Комплементарная медицина в современном здравоохранении / А. М. Василенко, М. М. Шарипова, К. Э. Лузина // Вестник Росздравнадзора. - 2011. - № 2. - С. 67-72.

2. Комплементарная медицина: за и против (взгляд врачей традиционной медицины) / Н. В. Башмакова, Е. В. Башмакова, М. В. Юдина, Н. Н. Бедрань. - Режим доступу: http://www.polykhrest.od.ua/other/years articles65.php.

3. Василенко А. М. Комплементарная медицина: пора определиться в терминологии / А. М. Василенко // Вестник восстановительной медицины. - 2009. - № 2. - C. 16-20.

4. Bland J. Does complementary and alternative medicine represent only placebo therapies? / J. Bland // Altern Ther Health Med. - 2008. - Mar-Apr. № 14 (2). - P. 16-18.

5. Vickers A. ABC of Complementary Medicine: the manipulative therapiesosteopathy and chiropractic / A. Vickers, C. Zollman // BMJ. - 1999. - № 319. P. 1176-1179.

6. Kligler B. Education Working Group, Consortium of Academic Health Centers for Integrative Medicine. Core competencies in integrative medicine for medical school curricula: a proposal / B. Kligler, V. Maizes, S. Schachter [et al.] // Acad. Med. - 2004. - Jun. № 79 (6). - P. 521-531.

7. Pearson N. J. The CAM Education Program of the National Center for Complementary and Alternative Medicine: an overview / N. J. Pearson, M. A. Chesney // Acad. Med. - 2007. - Oct. № 82 (10). - P. 921-926. - Comment : Gaylord S. A., Mann J. D. Rationales for CAM Education in Health Professions Training Programs. - P. 927-933.

8. Lee M. Y. Integrating complementary and alternative medicine instruction into health professions education:
3 робіт по лікуванню онкологічних захворювань [13-15] за принципами метааналізу.

Зрозуміло, можна було б розглядати й роль комплементарних засобів і методів для вирішення більш вузьких, індивідуальних або локальних завдань організму пацієнта, наприклад, для фіксації результату лікування або профілактичних цілей.

Висновки. 1. Поняття комплементарності та конгруентності можуть широко використовуватися для формалізації стратегії і тактики медичних дій у всьому ланцюжку етапів взаємодії лікаря та пацієнта - діагностики, лікування, реабілітації. Вони ж можуть бути кількісною базою для страхової медицини.

2. Для кількісного оцінювання комплементарності та конгруентності легко можуть бути застосовані лінійні функціонали, що мають зрозумілу для лікарів інтерпретацію.

organizational and instructional strategies / M. Y. Lee, R. Benn, L. Wimsatt [et al.] // Acad. Med. - 2007. - Oct. № 82 (10). P. 939-945.

9. Nedrow A. R. Collaborations between allopathic and complementary and alternative medicine health professionals: four initiatives / Nedrow A. R., Heitkemper M., Frenkel M. et al. // Acad. Med. - 2007. - Oct. № 82 (10). - P. 962-966.

10. Sharma U. Complementary medicine today: practitioners and patients / U. Sharma. - London : Routledge, 1995. - 272 p.

11. Конгруэнтность суставов. Малая медицинская энциклопедия. - М. : Медицинская энциклопедия, 19911996 г. - Т. 2. - 624 c.

12. Hutchinson T. A. The challenge of medical dichotomies and the congruent physician-patient relationship in medicine. Whole Person Care. A New Paradigm for the 21st Century / T. A. Hutchinson, J. Brawer. - New-York : Springer Science + Business Media, LLC, 2011. - P. 31-44.

13. Richardson M. A. Complementary and alternative medicine: opportunities and challenges for cancer management and research / M. A. Richardson, S. E. Straus // Semin Oncol. - 2002. - № 29. - P. 531.

14. Engel L. W. Development of therapeutics: opportunities within complementary and alternative medicine / L. W. Engel, S. E. Straus // Nat Rev Drug Discov. - 2002. - № 1. - P. 229.

15. Shen J. Use of complementary/alternative therapies by women with advanced-stage breast cancer / J. Shen, R. Andersen, P. S. Albert [et al.] // BMC Complement Altern Med. - 2002. - № 2. - P. 8.

16. Кількісні характеристики комплементарності та конгруентності інформаційних систем / Л. Ю. Бабінцева // Медична інформатика та інженерія. - 2014. - № 4. C. 35-38. 